\title{
The effects of glucose-induced oxidative stress on growth and extracellular matrix gene expression of vascular smooth muscle cells
}

\author{
P.C. Sharpe ${ }^{1,2}$, K. K.M. Yue ${ }^{1}$, M.A. Catherwood ${ }^{1}$, D. McMaster $^{3}$, E. R. Trimble ${ }^{1,2}$ \\ ${ }^{1}$ Department of Clinical Biochemistry, The Queen's University of Belfast, Belfast, UK \\ ${ }^{2}$ Department of Clinical Biochemistry, Royal Group of Hospitals Trust, Belfast, UK \\ ${ }^{3}$ Department of Medicine, The Queen's University of Belfast, Belfast, UK
}

\begin{abstract}
Summary Vascular smooth muscle cell (VSMC) dysfunction plays a role in diabetic macrovasculopathy and this may include abnormalities in growth characteristics and the extracellular matrix. As the actual mechanisms by which glucose induces VSMC dysfunction remain unclear, the aim of this study was to assess the potential role of glucose-induced oxidative stress. Porcine aortic VSMCs were cultured for 10 days in either $5 \mathrm{mmol} / \mathrm{l}$ normal glucose or $25 \mathrm{mmol} / \mathrm{l} \mathrm{D}$-glucose (high glucose). There was evidence of oxidative stress as indicated by a $50 \%$ increase in intracellular malondialdehyde $(p<0.05)$, increased mRNA expression of $\mathrm{CuZn}$ superoxide dismutase and Mn superoxide dismutase (by $51 \%$ and $37 \%$ respectively, $p<0.01$ ) and a $50 \%$ decrease in glutathione in $25 \mathrm{mmol} / \mathrm{l}$ D-glucose $(p<0.001)$. Growth was increased by $25.0 \%(p<0.01)$. mRNA expression of extracellular matrix proteins (collagens I, III, IV and fibronectin) was not altered by high glucose in these experimental conditions. Repletion of glutathione with $\mathrm{N}$-acetyl L-cysteine $(1 \mathrm{mmol} / \mathrm{l})$ in
\end{abstract}

VSMC grown in high glucose was associated with reduction in malondialdehyde and restored growth to that of normal glucose. The water soluble analogue of vitamin E, Trolox $(200 \mu \mathrm{mol} / \mathrm{l})$, reduced malondialdehyde concentrations, but had no effect on glutathione depletion or the increased growth rate seen with high glucose. The addition of buthionine sulphoximine $(10 \mu \mathrm{mol} / \mathrm{l})$ to VSMC cultured in normal glucose reduced glutathione, increased malondialdehyde and increased growth to a similar extent as that found in high glucose alone. These results suggest that thiol status, rather than lipid peroxides, is a key factor in modulating VSMC growth and that mRNA expression of extracellular matrix proteins is not increased in VSMC under conditions of glucose-induced oxidative stress. [Diabetologia (1998) 41: 1210-1219]

Keywords Diabetic macrovasculopathy, oxidative stress, vascular smooth muscle cells, extracellular matrix, antioxidant enzymes, glutathione
Received: 26 November 1997 and in revised form: 28 April 1998

Corresponding author: Dr. P.C. Sharpe, Department of Clinical Biochemistry, The Queen's University of Belfast, Institute of Clinical Science, Grosvenor Rd, Belfast, BT12 6BA, UK Abbreviations: VSMC, Vascular smooth muscle cells; DMEM, Dulbecco's modified Eagle medium; PBS, phosphate buffered saline; SOD, superoxide dismutase; GPX, glutathione peroxidase; RT-PCR, reverse transcriptase mediated polymerase chain reaction; BSO, buthionine sulphoximine; TAE, Tris acetate EDTA; NAC, N-acetyl L-cysteine; GAPDH, glyceraldehyde-3 phosphate dehydrogenase; YGCS, gamma glutamyl cysteine synthetase
Diabetes mellitus is a major risk factor for atherosclerosis. In population based studies diabetes is associated with an increased incidence of coronary heart disease [1], cerebrovascular disease and peripheral vascular disease [2]. The high prevalence of macrovascular disease is partly explained by the increased frequency of conventional risk factors and partly by risk factors specific for diabetes including hyperglycaemia, hyperinsulinaemia and dyslipidaemia. The view that diabetic vasculopathy is, at least in part, related to excess free radicals is supported by evidence such as increased lipid peroxidation [3] and reduced antioxidant reserve in patients with diabetes [4] and from studies showing a direct cytotoxic effect of free 
radicals and their metabolic end-products (lipid hydroperoxides) on endothelial cells [5].

High ambient glucose has been shown to affect endothelial and other vascular cells [6], such as is shown by the induction of apoptosis in cultured endothelial cells [7] and endothelial dysfunction in vivo [8]. Dysfunction of vascular smooth muscle cells (VSMC) is also known to occur in diabetes. Their growth and proliferation in the arterial intima is one key feature in the atherosclerotic lesion [9] and hyperproliferation has also been shown in VSMC cultured in high glucose concentrations [10]. There is evidence to suggest that reactive oxygen intermediates can act as stimulants of proliferation for VSMC [10, 11], although there are a number of other recognised factors such as insulin [12], protein kinase C [13], and potent growth factors such as platelet-derived growth factor, fibroblast growth factor and heparin-binding epidermal growth factor-like growth factor [14]. The gene expression of the third potent growth factor can be increased by oxidative stress [14] and oxidant-mediated activation of protein kinase $\mathrm{C}$ has also been reported [15]. Studies also suggest that VSMC which have migrated to the intima in atherosclerotic lesions, have changed from a contractile to a synthetic phenotype which could have profound effects on the capacity of the cell to respond to various agonists [16]. Non-atherosclerotic changes could also be important in the development of diabetic macroangiopathy and VSMC may be intimately involved in this process. Increases in the extracellular matrix proteins, fibronectin and collagen IV have been reported in the tunica media in diabetic patients without atherosclerotic plaques [17]. Therefore glucoseinduced dysfunction of VSMC could involve increased growth rates, alteration in phenotype and increased synthesis of extracellular matrix proteins. The role of glucose-induced oxidative stress in these processes has not been extensively investigated.

Although glucose-induced oxidative stress possibly is important in promoting VSMC growth, there is little doubt that oxidative stress can also induce cell death [18]; therefore both the degree of oxidant stress and cell type must have potential importance in the growth response. Endogenous antioxidant defences to protect against attack by reactive oxygen species include the antioxidant enzymes superoxide dismutase (SOD) and glutathione peroxidase (GPX) and the non-enzymatic aqueous phase antioxidant glutathione, which is perhaps the most important and versatile protector [19]. The reduced glutathione-oxidised glutathione couple is the major redox buffer in the cell and is known to be involved (along with oxidative stress) in regulation and activation of transcription factors such as NF- $\kappa \mathrm{B}$ (nuclear factor kappa B) and AP-1 (activator protein 1). Activation of these transcription factors leads to the rapid induction of genes encoding both growth and defence proteins $[20,21]$. Our aim was to assess the evidence for the existence of glucose-induced oxidative stress in VSMC and its role in VSMC dysfunction as displayed by growth abnormalities and gene expression of extracellular matrix proteins.

\section{Materials and methods}

All materials were obtained from Sigma Chemical Co. Ltd (Poole, Dorset, UK) unless otherwise stated.

VSMC isolation and culture. We isolated VSMC from porcine aortae (donors were between 50-70 kg, of both sexes and less than 24 months old) obtained from the local abbatoir. The intima and adventitial layers were stripped and the medial segment cut into small pieces approximately $1 \mathrm{~mm}^{2}$ and transferred onto the growing surface of $25 \mathrm{~cm}^{2}$ tissue culture flasks (Corning, Bibby Sterilin Ltd, Stone, Staff, UK) pre-moistened with fetal calf serum (FCS, PAA Laboratories GmbH, Linz, Austria). Following this, Dulbecco's modified Eagle medium (DMEM, GibcoBRL, Life Technologies, Paisley, UK) supplemented with antibiotics (benzylpenicillin $60 \mu \mathrm{g} / \mathrm{ml}$ and streptomycin sulphate $100 \mu \mathrm{g} / \mathrm{ml})$, amphotericin B $(2.5 \mu \mathrm{g} / \mathrm{ml}$, GibcoBRL) and $10 \%$ (v/v) fetal calf serum (growth medium) was added to the flasks. The flasks were placed in an incubator $\left(37^{\circ} \mathrm{C}, 5 \% \mathrm{CO}_{2}\right)$ and left undisturbed for 7 days. After this the growth medium (DMEM/10\% fetal calf serum) was replaced twice weekly. Within 7-10 days VSMC grew out from the explants reaching confluence within 2-3 weeks and were harvested with $0.125 \%$ trypsin (type II, porcine pancreas, Difco Laboratories Inc, Detroit, Mich., USA) and split for further culture into $75 \mathrm{~cm}^{2}$ tissue culture flasks. Cells were confirmed as VSMC by their typical morphology and positive immunofluorescence staining against smooth muscle $\alpha$-actin.

For the different experiments, cells were cultured for 10 days in the appropriate conditions. Growth medium was changed twice weekly. All experiments were done on cells up to and including subculture number 5 (preliminary experiments had shown no significant differences in morphology, growth rates or intracellular activities and concentrations of the analytes of interest up to this subculture).

Viability of cultures. Trypan blue solution ( $0.4 \%)$ was added to aliquots of cell suspensions in a 1:1 ratio and allowed to stand for $10 \mathrm{~min}$ at room temperature. A haemocytometer was used to count live and dead cells, and per cent viabilities were calculated. Lactate dehydrogenase activities were also measured in the supernatants using dry-film technology on a Vitros 750 analyser (Johnson \& Johnson Clinical Diagnostics, Amersham, Bucks, UK).

Growth curve experiments. For all experiments VSMC were seeded $\left(1.5 \times 10^{5}\right.$ cells) into $25 \mathrm{~cm}^{2}$ tissue culture flasks (day 0 ) under the various experimental conditions. Following trypsinisation, cell counts were performed on a Coulter counter (Coulter Electronics Ltd, Luton, Beds, UK); three separate readings were taken and the mean calculated. Cell counts were done on days $2,4,6,8$ and 10 in all cases.

Assessment of mitotic and apoptotic rates. Cytospins (600 $\mathrm{rpm} \times 10 \mathrm{~min}$ ), approximately $10^{5}$ cells per slide, were prepared following trypsinisation of VSMC cultured under the different conditions for 6,8 and 10 days. VSMC were stained with standard Haematoxylin \& Eosin (H\&E) and Giemsa. 
For apoptosis, cells were inspected (500 cells per slide) to identify the typical nuclear condensation changes of this condition. Mitosis was assessed by counting mitotic figures (expressed as $\%$ of total of 3000 cells). Flow cytometric analysis (Epics ELITE flow cytometer, Coulter Corporation, Fla., USA) of propidium iodide stained cells was also used to identify proliferating cells ( $\% \mathrm{G} 2+\mathrm{M}+\mathrm{S})$. VSMC were trypsinised, fixed in $70 \%$ ethanol and stained with propidium iodide $(30 \mu \mathrm{g} / \mathrm{ml}$ in phosphate-buffered saline (PBS), $\mathrm{pH} 7.6,30 \mathrm{~min}$ ). At least 10 000 events were measured for each sample and red fluorescence $(623 \mathrm{~nm})$ was detected to determine DNA content per nucleus. DNA histograms were analysed using Wincycle Software (Phoenix Flow Systems, San Diego, Calif., USA) and the per cent $\mathrm{G} 2+\mathrm{M}+\mathrm{S}$ calculated.

Harvesting of VSMC for measurement of malondialdehyde $(M D A)$, glutathione (GSH), enzyme activities and protein activities. Monolayers were rinsed twice with ice-cold Hanks Balanced Salt Solution (HBSS, without calcium, magnesium and phenol red, GibcoBRL) and the cells collected using a disposable cell scraper (Sarstedt Ltd, Leicester, UK). The cells were centrifuged at $225 \mathrm{~g}$ at $4{ }^{\circ} \mathrm{C}$ for $5 \mathrm{~min}$ and the cell pellet stored at $-80^{\circ} \mathrm{C}$ prior to the stage of cell lysis.

Cell lysis and homogenization. Cell pellets were removed from the freezer and resuspended in $0.1 \%$ Triton $\mathrm{X}-100$ (BDH Chemicals Ltd) in PBS ( $\mathrm{pH} 7.4)$. Sonication was done with two $15 \mathrm{~s}$ bursts on a sonicator (Lucas Dawe Ultrasonics, London, UK), using a microtip (setting number 4 , continuous cycle) with a $20 \mathrm{~s}$ cooling period separating the two bursts. An aliquot of the whole cell homogenate was removed for protein analysis. The rest of the homogenate was centrifuged at $3000 \mathrm{~g}$ for $30 \mathrm{~min}$ at $4{ }^{\circ} \mathrm{C}$ and aliquots of the resulting supernatant taken for the analyses outlined below. CuZnSOD, MnSOD and GPX activities were analysed immediately. CuZnSOD protein and malondialdehyde samples were stored at $-80^{\circ} \mathrm{C}$ prior to analysis. The samples for glutathione were stabilized by the addition of 1 part $10 \%$ sulphosalicylic acid to 2 parts sample. After centrifugation at $13000 \mathrm{~g}$ for $5 \mathrm{~min}$, the resulting supernatant was stored at $-80^{\circ} \mathrm{C}$.

Protein measurement. Total protein was measured using a bicinchoninic acid (BCA) protein assay reagent kit (Pierce and Warriner Ltd, Chester, UK). Bovine serum albumin (BSA) was used as the standard.

Malondialdehyde. Malondialdehyde was measured by HPLC with fluorimetric detection [22].

Glutathione. This was measured by the method described by Griffith [23] which has been automated on the Cobas Fara centrifugal analyser (Roche Products Ltd, Welwyn Garden City, Herts, UK).

$\mathrm{CuZnSOD}$ protein concentration. The concentration of $\mathrm{CuZn-}$ SOD protein was measured using an ELISA [24].

CuZnSOD, MnSOD \& GPX activities. Total superoxide dismutase (SOD) activity was measured using the method of L'Abbe and Fischer [25] adapted for the Cobas Fara centrifugal analyser. MnSOD activity is resistant to incubation at room temperature with $2 \mathrm{mmol} / \mathrm{l}$ potassium cyanide $(\mathrm{BDH}$ Chemicals Ltd) for $45 \mathrm{~min}$. CuZnSOD activity was subsequently calculated by the subtraction of MnSOD activity from total SOD activity. The enzyme activity of GPX was determined by the method of McMaster et al. [26].
Extraction of RNA from VSMC. Total cellular RNA was extracted from cultured cells by the acid-guanidinium thiocyanate-phenol-chloroform method of Chomczynski and Sacchi [27].

Northern blot analysis. Aliquots $(30 \mu \mathrm{g})$ of total RNA were separated by electrophoresis on a $1 \%$ agarose-formaldehyde gel. Transfer of the denatured RNA was to a charged nylon filter (Hybond $\mathrm{N}^{+}$, Amersham Internat plc, Little Chalford, Bucks, UK). Hybridization was done in a Tecne Hybridizer HB-1D hybridization oven (Techne Ltd, Duxford, Cambridge,

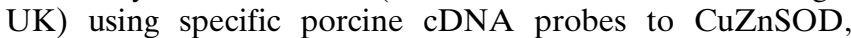
MnSOD and GPX mRNA prepared by reverse-transcriptase mediated polymerase chain reaction (RT-PCR) as described in the following section. A porcine cDNA probe to glyceraldehyde-3 phosphate dehydrogenase (GAPDH) was also prepared by RT-PCR and used as a "house-keeping" gene. Prehybridization was at $65^{\circ} \mathrm{C}$ for $30 \mathrm{~min}$ following the addition of Quickhyb hybridization solution $\left(0.2 \mathrm{ml}\right.$ per $\mathrm{cm}^{2}$, Stratagene Ltd, Cambridge, UK.). cDNA probes (75-100 ng) were labelled using the Prime-It II Random Primer Labelling kit (Stratagene) and $50 \mu \mathrm{Ci}{ }^{32} \mathrm{P} \mathrm{dCTP}$ (Amersham, Redivue, 370 $\mathrm{MBq} / \mathrm{ml}$ ). Hybridization was carried out for $2 \mathrm{~h}$ at $65^{\circ} \mathrm{C}$ following which the membrane was washed (at $42^{\circ} \mathrm{C}$ ) twice in $2 \times$ standard sodium citrate (SSC), $0.1 \%$ sodium dodecyl sulphate (SDS) for $15 \mathrm{~min}$, once with $1 \times \mathrm{SSC}, 0.1 \%$ SDS for $15 \mathrm{~min}$ and finally with $0.2 \times \mathrm{SSC}, 0.1 \% \mathrm{SDS}$ for $15 \mathrm{~min}$.

The membranes were analysed on a Bio-Rad Molecular Imager system GS-525 (Bio-Rad Laboratory Ltd, Hemel Hempstead, Herts, UK). Band intensities were quantified using the attached software by volume analysis with local background subtraction. GAPDH mRNA expression was used to correct for loading inequalities.

Reverse Transcriptase-mediated Polymerase Chain Reaction $(R T-P C R)$. The following PCR primers were used (EcoRI internal restriction sites underlined):

I. MnSOD (Acc No. X64057); CBS1: GGAATTCCAGCTGCACCACAGCGAGC (100 pmol/reaction); CBA1: GGAATTCGATCCCCAGCAGCGGAACC (100 pmol/reaction)

II. CuZnSOD (Acc No. P04178); CBS2: GGAATTCT(T/ C)CA(T/C)GTNCA(T/C)CA(A/G)TT(T/C)GG (640 pmol/ reaction); CBA2: GGAATTCC(A/G)TCNGG(T/C)TT(T/ C)TC(A/G)TGNAC (1280 pmol/reaction)

III. GPX I [28-30] ; CBS3: GGGAATTCCCNTG(T/C)AA(T/ C)CA(A/G)TT(T/C)GG (320 pmol/reaction); CBA3: GGGAATTCG(T/C)(T/C)T(C/G)(A/G/T)AT(A/G)TCNG-

$\mathrm{G}(\mathrm{T} / \mathrm{C}) \mathrm{TC}(1290 \mathrm{pmol} / \mathrm{reaction})$

IV. GAPDH (Acc Nos. U48832, X94251); CBS4: GGGAATTCACNATGGA(A/G)AA(A/G)GCNGG (320 pmol/reaction); CBA4: GGAATTCTTGGAGGCCATGTGGACC (100 pmol/reaction)

Oligo(dT) primed first strand cDNA synthesis was carried out on total RNA ( $1 \mu \mathrm{g})$ with a reverse transcription system (Promega Corp, Madison, Wis., USA) but using superscript II Rnase $\mathrm{H}^{-}$reverse transcriptase (GibcoBRL). PCR reagents were obtained from Promega. An aliquot $(3 \mu \mathrm{l})$ of the first strand cDNA reaction was added directly to the PCR mix containing $0.25 \mathrm{mmol} / \mathrm{l}$ of each deoxynucleotide triphosphate (dNTPs)(dATP, dCTP, dGTP, dTTP), 5.0 U Taq DNA polymerase, sense and antisense primers in $100 \mu \mathrm{l}$ of $1 \times$ Taq DNA polymerase buffer $[50 \mathrm{mmol} / \mathrm{l} \mathrm{KCl}, 10 \mathrm{mmol} / 1 \mathrm{Tris}-\mathrm{HCl}(\mathrm{pH}$ 9.0), $0.1 \%$ Triton $\mathrm{X}-100] . \mathrm{MgCl}_{2}$ to a final concentration of $1.5 \mathrm{mmol} / \mathrm{l}$ was also added. A Perkin Elmer DNA Thermal Cycler (Perkin Elmer, Beaconsfield, Bucks, UK) was used with the following cycling times and temperatures; $94^{\circ} \mathrm{C}$ for $2 \mathrm{~min}$, 
Table 1. Intracellular malondialdehyde and glutathione in VSCM cultured for 10 days under varying conditions

\begin{tabular}{lll}
\hline Culture conditions & $\begin{array}{l}\text { MDA } \\
(\mathrm{nmol} / \mathrm{mg} \text { protein })\end{array}$ & $\begin{array}{l}\text { GSH } \\
(\mathrm{nmol} / \mathrm{mg} \text { protein })\end{array}$ \\
\hline $5 \mathrm{mmol} / \mathrm{l} \mathrm{D}$-glucose & $1.20 \pm 0.12$ & $1.36 \pm 0.16$ \\
$25 \mathrm{mmol} / \mathrm{l}$ D-glucose & $1.81 \pm 0.25^{\mathrm{a}}$ & $0.67 \pm 0.09^{\mathrm{b}}$ \\
$5 \mathrm{mmol} / \mathrm{l} \mathrm{D}$-glucose + & & \\
$20 \mathrm{mmol} / \mathrm{l} \mathrm{mannitol}$ & $1.34 \pm 0.16$ & $1.68 \pm 0.22$ \\
$5 \mathrm{mmol} / \mathrm{l} \mathrm{D}$-glucose + & & \\
$20 \mathrm{mmol} / \mathrm{l} \mathrm{L}$-glucose & $1.15 \pm 0.15$ & $1.23 \pm 0.16$
\end{tabular}

MDA, malondialdehyde, GSH, glutathione, $n=12$ independent experiments (in triplicate), ${ }^{\mathrm{a}} p<0.05,{ }^{\mathrm{b}} p<0.001$, $5 \mathrm{mmol} / \mathrm{l} \mathrm{vs} 25 \mathrm{mmol} / \mathrm{l}$ D-glucose

followed by 5 cycles of $50^{\circ} \mathrm{C}$ for $1 \mathrm{~min}, 72^{\circ} \mathrm{C}$ for $40 \mathrm{~s}, 94^{\circ} \mathrm{C}$ for $45 \mathrm{~s}$, and 30 cycles of $60^{\circ} \mathrm{C}$ for $1 \mathrm{~min}, 72^{\circ} \mathrm{C}$ for $40 \mathrm{~s}$ and $94^{\circ} \mathrm{C}$ for $45 \mathrm{~s}$, and then $72^{\circ} \mathrm{C}$ for $5 \mathrm{~min}$. Reaction products $(10 \mu \mathrm{l})$ were separated by $1.2 \%$ agarose gel electrophoresis in $1 \times$ Tris acetate EDTA (TAE) buffer and visualised by staining with ethidium bromide $(0.5 \mu \mathrm{g} / \mathrm{ml})$.

Subcloning. Purification of PCR products was done using the Wizard PCR purification kit (Promega) and subcloned into pGEM-T (Promega). Verification of transformation was done by PCR screening of individual colonies (clones).

DNA sequencing and sequence analysis. The sequence of cDNA inserts was verified. Plasmid DNA was denatured and sequenced in both directions using sequenase V2.0 (USB, Cleveland, Ohio, USA).

$m R N A$ expression of extracellular matrix proteins. VSMC were grown for a period of 10 days in the presence of either $5 \mathrm{mmol} / \mathrm{l}$ or $25 \mathrm{mmol} / \mathrm{l} \mathrm{D}$-glucose. Total RNA was extracted as described above. cDNA to fibronectin and collagen IV were obtained from Human Genome Mapping Project (HGMP, Cambridge, UK). Plasmids pMCol1a-1 (collagen I, mouse) and pRGR5 (collagen III, rat) were obtained as gifts from Professor Eero Vuorio (Department of Medical Biochemistry and Molecular Biology, University of Turku, Turku, Finland) [31, 32]. Northern blotting and hybridization was as described previously with the exception that the hybridization temperature was reduced to $60^{\circ} \mathrm{C}$.

Other materials. D-glucose, D-mannitol, L-glucose, N-acetyl L-cysteine and Trolox were obtained from Sigma Chemical Co. (Poole, Dorset, UK). L-Buthionine-S,R,-sulphoximine ( $99 \%$, BSO) was obtained from Janssen Chimica (Acros, Newton, Cheshire, UK).
Statistical analysis. The normality of data was assessed using the Kolmogorov-Smirnov Normality test; comparison between groups was assessed by analysis of variance (ANOVA) and paired $t$ tests. Northern blots were analysed by paired $t$ tests. All results are expressed as mean \pm SEM.

\section{Results}

Cell viability. In all experiments more than $92 \%$ of VSMC were viable as assessed by trypan blue dye exclusion and lactate dehydrogenase activities in the supernatant were not different from those cultured in $5 \mathrm{mmol} / \mathrm{l} \mathrm{D}$-glucose (results not shown).

Evidence of glucose-induced oxidative stress. In VSMC cultured in $25 \mathrm{mmol} / \mathrm{l} \mathrm{D}$-glucose for 10 days intracellular malondialdehyde was increased (by $50 \%$ ) $(p<0.05)$, and glutathione was decreased (by $50 \%$ ) $(p<0.001)$, but this was not found in either equimolar L-glucose (glycation control) or mannitol (osmotic control) (Table 1). Glutathione disulphide was less than $3.0 \%$ of total glutathione in $5 \mathrm{mmol} / \mathrm{l}$ and less than $3.6 \%$ in $25 \mathrm{mmol} / \mathrm{l} \mathrm{D}$-glucose (Table 1 ) and there was no difference between $5 \mathrm{mmol} / \mathrm{l}$ and $25 \mathrm{mmol} / \mathrm{l} \mathrm{D}$ glucose ( $n=4$ experiments, results not shown).

In the presence of $25 \mathrm{mmol} / \mathrm{l} \mathrm{D}$-glucose $(n=7)$ mRNA expression of CuZnSOD was increased 1.51fold and that of MnSOD 1.37-fold. There was no alteration in GPX mRNA expression (Fig.1). In a smaller number of experiments $(n=3)$ mRNA expression of $\mathrm{CuZnSOD}$ and MnSOD were not altered in the presence of either equimolar L-glucose or mannitol (Table 2).

The concentration of $\mathrm{CuZnSOD}$ protein was increased in $25 \mathrm{mmol} / \mathrm{l}$ compared with $5 \mathrm{mmol} / \mathrm{l} \mathrm{D}$-glucose $(8.38 \pm 0.49$ vs $4.01 \pm 0.34 \mathrm{ng} / \mathrm{mg}$ protein, $p<0.001, n=12)$. This was not found with either Lglucose or mannitol $(4.65 \pm 0.25$ and $3.78 \pm 0.29 \mathrm{ng} /$ $\mathrm{mg}$ protein respectively). Enzymatic activities of $\mathrm{Cu}-$ ZnSOD, MnSOD and GPX were similar for cells grown in $5 \mathrm{mmol} / \mathrm{l}$ and $25 \mathrm{mmol} / \mathrm{l} \mathrm{D}$-glucose $(\mathrm{CuZn}$ SOD: $62.2 \pm 4.1$ vs $64.0 \pm 4.5 \mathrm{U} / \mathrm{mg}$ protein; MnSOD: $3.4 \pm 0.4$ vs $2.9 \pm 0.3 \mathrm{U} / \mathrm{mg}$ protein; GPX: $25.0 \pm 2.5$ vs $16.8 \pm 3.2 \mathrm{mU} / \mathrm{mg}$ protein, $5 \mathrm{mmol} / \mathrm{l}$ vs $25 \mathrm{mmol} / \mathrm{l}$ D-glucose, $n=12$ ).

Table 2. mRNA of antioxidant enzymes in VSMC cultured for 10 days in $5 \mathrm{mmol} / \mathrm{l} \mathrm{D}$-glucose, $25 \mathrm{mmol} / \mathrm{l} \mathrm{D}$-glucose, $5 \mathrm{mmol} / \mathrm{l}$ D-glucose plus $20 \mathrm{mmol} / \mathrm{l} \mathrm{L}$-glucose and $5 \mathrm{mmol} / \mathrm{l} \mathrm{D}$-glucose plus $20 \mathrm{mmol} / 1 \mathrm{mannitol}$

\begin{tabular}{lllll}
\hline Antioxidant enzyme & $5 \mathrm{mmol} / \mathrm{l} \mathrm{D}$-glucose & $25 \mathrm{mmol} / \mathrm{l} \mathrm{D}$-glucose & $\begin{array}{l}5 \mathrm{mmol} / \mathrm{l} \mathrm{D} \text {-glucose }+ \\
20 \mathrm{mmol} / \mathrm{L} \text {-glucose }\end{array}$ & $\begin{array}{l}5 \mathrm{mmol} / \mathrm{l} \mathrm{D} \text {-glucose }+ \\
20 \mathrm{mmol} / \mathrm{mannitol}\end{array}$ \\
\hline CuZn SOD & & & $1.09 \pm 0.10$ & $1.14 \pm 0.09$ \\
Mn SOD & 1.0 & $1.51 \pm 0.09^{\mathrm{a}}$ & $1.11 \pm 0.07$ \\
GPX & 1.0 & $1.37 \pm 0.10^{\mathrm{a}}$ & $0.93 \pm 0.11$ & \\
\hline
\end{tabular}

Volume analysis corrected for glyceraldehyde-3 phosphate dehydrogenase; $5 \mathrm{mmol} / \mathrm{l}=1.0, n=7$ independent experiments for $5 \mathrm{mmol} / \mathrm{l}$ vs $25 \mathrm{mmol} / \mathrm{l} \mathrm{D}$-glucose, $n=3$ for $5 \mathrm{mmol} / \mathrm{l} \mathrm{D}$-glu- cose, $5 \mathrm{mmol} / \mathrm{l} \mathrm{D}$-glucose plus L-glucose and $5 \mathrm{mmol} / \mathrm{l} \mathrm{D}$-glucose plus mannitol. a $p<0.01 \mathrm{cf} 5 \mathrm{mmol} / 1 \mathrm{D}$-glucose 


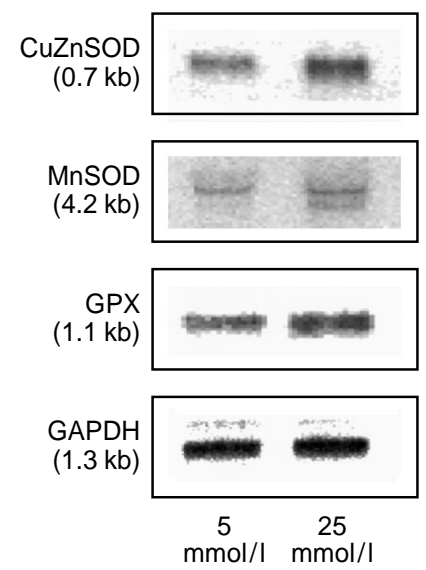

Fig. 1. $\mathrm{mRNA}$ expression of CuZnSOD (0.7 kb), MnSOD (4.2 $\mathrm{kb})$ and glutathione peroxidase (GPX, $1.1 \mathrm{~kb}$ ) in VSMC cultured for 10 days in either $5 \mathrm{mmol} / \mathrm{l}$ or $25 \mathrm{mmol} / \mathrm{l} \mathrm{D}$-glucose

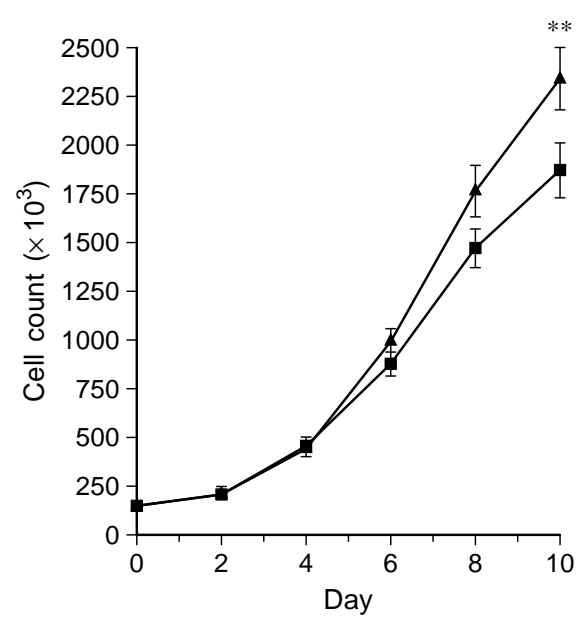

Fig. 2. Growth curves of VSMC cultured in $5 \mathrm{mmol} / 1$ and $25 \mathrm{mmol} / \mathrm{l} \mathrm{D}$-glucose for 10 days. $* * p<0.01,25 \mathrm{mmol} / \mathrm{l} \mathrm{vs}$ $5 \mathrm{mmol} / \mathrm{l} .(n=4) \longrightarrow-5 \mathrm{mmol} / \mathrm{l} \mathrm{D}$-glucose, $\longrightarrow 25 \mathrm{mmol} / \mathrm{l}$ D-glucose

There was an increased number of cells in $25 \mathrm{mmol} / \mathrm{l} \mathrm{D}$-glucose from 6 days onwards. VSMC were increased by $25.0 \pm 1.1 \%$ compared with $5 \mathrm{mmol} / \mathrm{l} \mathrm{D}$-glucose at day $10(p<0.01)$ (Fig. 2$)$. This increase was not repeated in equimolar L-glucose or mannitol (results not shown). There were no differences in mRNA expression of the extracellular matrix proteins in VSMC cultured in $25 \mathrm{mmol} / \mathrm{l} \mathrm{D}$-glucose (Table 3, Fig. 3).

Effects of antioxidants. The following antioxidants were added to VSMC cultured in $25 \mathrm{mmol} / \mathrm{l} \mathrm{D}$-glucose; $\mathrm{N}$-acetyl L-cysteine (NAC, $0.5 \mathrm{mmol} / \mathrm{l}$ and $1.0 \mathrm{mmol} / \mathrm{l})$ and Trolox $(200 \mu \mathrm{mol} / \mathrm{l})$ over the 10 day period of culture. Concentrations of NAC greater than $1 \mathrm{mmol} / \mathrm{l}$ were associated with reduced cellular viability. The addition of NAC $(0.5 \mathrm{mmol} / \mathrm{l}$ and $1.0 \mathrm{mmol} / \mathrm{l})$ and Trolox $(200 \mu \mathrm{mol} / \mathrm{l})$ reduced intracel-

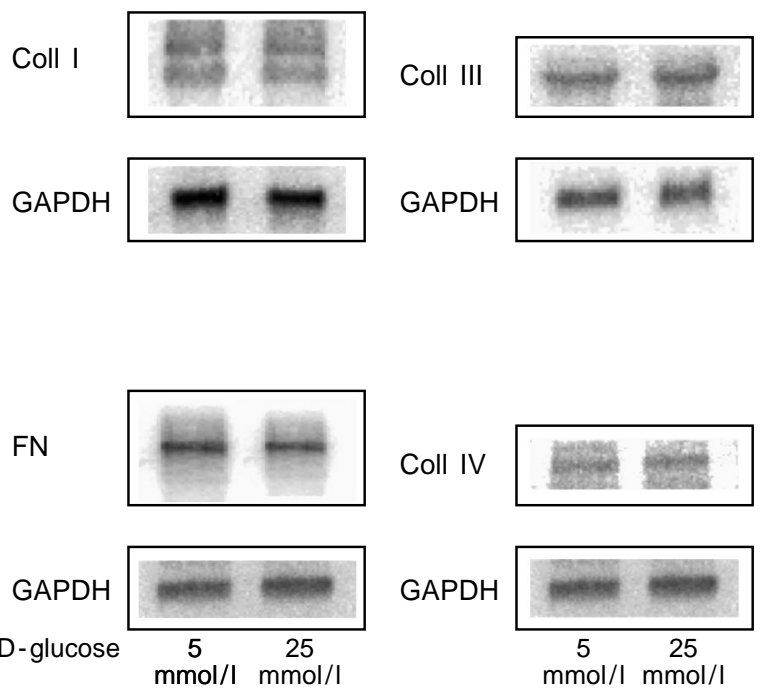

Fig.3. mRNA expression of the extracellular matrix proteins, collagens I (5.4 kb, $6.4 \mathrm{~kb})$, III (6 kb) and IV $(6.5 \mathrm{~kb})$ and fibronectin $(7.9 \mathrm{~kb})$ in VSMC cultured for 10 days in either $5 \mathrm{mmol} / \mathrm{l}$ or $25 \mathrm{mmol} / \mathrm{l} \mathrm{D}$-glucose

lular malondialdehyde concentrations to levels which were not significantly different from those of VSMC cultured in $5 \mathrm{mmol} / \mathrm{l} \mathrm{D}$-glucose. Only NAC (and in particular the $1 \mathrm{mmol} / \mathrm{l}$ concentration) had an effect in increasing the glutathione concentration towards that of VSMC cultured in $5 \mathrm{mmol} / \mathrm{l} \mathrm{D}$-glucose (Fig. 4).

Independent experiments $(n=3)$ suggest that although Trolox reduced the increased mRNA expression to normal, $0.5 \mathrm{mmol} / 1$ and $1 \mathrm{mmol} / 1 \mathrm{NAC}$ had no effect in doing so (Table 4, Fig. 5).

The addition of both $0.5 \mathrm{mmol} / 1$ and $1.0 \mathrm{mmol} / \mathrm{l}$ NAC to VSMC culture in $25 \mathrm{mmol} / \mathrm{l} \mathrm{D}$-glucose for 10 days normalised their growth $(25 \mathrm{mmol} / \mathrm{l} \mathrm{D}$-glucose; growth increased by $24.5 \pm 2.6 \%$ compared with $5 \mathrm{mmol} / \mathrm{l}$ D-glucose at day $10, p<0.05$ : $25 \mathrm{mmol} / \mathrm{l} \mathrm{D}$-glucose plus $0.5 \mathrm{mmol} / \mathrm{l} \mathrm{NAC}$; increased by $2.9 \% \pm 5.8 \%: 25 \mathrm{mmol} / \mathrm{l} \mathrm{D}$-glucose plus $1 \mathrm{mmol} / \mathrm{l}$ NAC; decreased by $5.5 \pm 7.5 \%, n=3$, growth curves not shown). Trolox $(200 \mu \mathrm{mol} / \mathrm{l})$ failed to reduce the increased growth of VSMC cultured in $25 \mathrm{mmol} / \mathrm{l} \mathrm{D}$ glucose (growth curve not shown). VSMC numbers were increased by $24.5 \pm 2.6 \%$ in $25 \mathrm{mmol} / \mathrm{l} \mathrm{D}$-glucose and by $28.9 \pm 7.5 \%$ in $25 \mathrm{mmol} / \mathrm{l} \mathrm{D}$-glucose plus Trolox at day 10 ( $n=3, p<0.05$ for each condition).

Effects of buthionine sulphoximine (BSO). The concentration of BSO added to VSMC cultured in $5 \mathrm{mmol} / \mathrm{l} \mathrm{D}$-glucose was titrated to produce a similar reduction in $\mathrm{GSH}$ as was seen in $25 \mathrm{mmol} / \mathrm{l} \mathrm{D}$-glucose (range $0.5-10 \mu \mathrm{mol} / \mathrm{l}$ ). The addition of $10 \mu \mathrm{mol} / 1 \mathrm{BSO}$ to VSMC cultured in $5 \mathrm{mmol} / \mathrm{l} \mathrm{D}$-glucose led to a significant reduction in GSH $(0.65 \pm 0.12$ vs $1.87 \pm 0.22$ $\mathrm{nmol} / \mathrm{mg}$ protein, $5 \mathrm{mmol} / \mathrm{l} \mathrm{D}$-glucose plus $10 \mu \mathrm{mol} / \mathrm{l}$ BSO vs $5 \mathrm{mmol} / \mathrm{l} \mathrm{D}$-glucose, $n=5, p<0.01$ ) and an 
Table 3. mRNA expression of fibronectin and collagens I, III and IV in VSMC cultured for 10 days in either $5 \mathrm{mmol} / \mathrm{l}$ or $25 \mathrm{mmol} / \mathrm{l} \mathrm{D}$-glucose

\begin{tabular}{lll}
\hline & $5 \mathrm{mmol} / \mathrm{l} \mathrm{D}$-glucose & $25 \mathrm{mmol} / \mathrm{l} \mathrm{D}$-glucose \\
\hline Fibronectin & 1.0 & $1.07 \pm 0.07$ \\
Collagen I & 1.0 & $1.02 \pm 0.12$ \\
Collagen III & 1.0 & $0.95 \pm 0.06$ \\
Collagen IV & 1.0 & $1.07 \pm 0.13$ \\
\hline
\end{tabular}

Volume analysis corrected for glyceraldehyde- 3 phosphate dehydrogenase. $5 \mathrm{mmol} / \mathrm{l}=1.0,(n=5$ independent experiments for fibronectin and collagen IV, $n=3$ for collagen I and III)

Table 4. mRNA expression of CuZnSOD and MnSOD in VSMC cultured for 10 days under differing conditions

\begin{tabular}{lll}
\hline Condition & CuZnSOD & MnSOD \\
\hline $5 \mathrm{mmol} / \mathrm{l} \mathrm{D}$-glucose & 1.0 & 1.0 \\
$25 \mathrm{mmol} / \mathrm{l} \mathrm{D}$-glucose & $1.50 \pm 0.11$ & $1.33 \pm 0.10$ \\
$25 \mathrm{mmol} / \mathrm{l}+1 \mathrm{mmol} / \mathrm{l} \mathrm{NAC}$ & $1.39 \pm 0.13$ & $1.52 \pm 0.17$ \\
$25 \mathrm{mmol} / \mathrm{l}+200 \mu \mathrm{mol} / \mathrm{l} \mathrm{Trolox}$ & $1.16 \pm 0.18$ & $1.08 \pm 0.15$ \\
\hline
\end{tabular}

$n=3$ independent experiments, $5 \mathrm{mmol} / 1=1.0$

increase in malondialdehyde $(1.69 \pm 0.13$ vs $1.05 \pm 0.08 \mathrm{nmol} / \mathrm{mg}$ protein, $n=5, p<0.05$ ) (Fig. 6)

In two experiments, mRNA expression of CuZnSOD and MnSOD was increased in VSMC cultured in $5 \mathrm{mmol} / \mathrm{l} \mathrm{D}$-glucose plus $10 \mu \mathrm{mol} / \mathrm{l} \mathrm{BSO}$ compared with $5 \mathrm{mmol} / \mathrm{l} \mathrm{D}$-glucose (CuZnSOD; by 1.83 -fold and 1.20-fold, MnSOD; by 1.52-fold and 1.19-fold).

The addition of $10 \mu \mathrm{mol} / \mathrm{l} \mathrm{BSO}$ to VSMC cultured in $5 \mathrm{mmol} / \mathrm{l} \mathrm{D}$-glucose was associated with an increase in VSMC growth to a similar extent as demonstrated in $25 \mathrm{mmol} / \mathrm{l}$ D-glucose (Fig. 7).

Mitotic and apoptotic rates. There was no evidence of apoptosis, as assessed by morphological criteria, in any of the above conditions $(5 \mathrm{mmol} / \mathrm{l} \mathrm{D}$-glucose, $25 \mathrm{mmol} / \mathrm{l} \mathrm{D}$-glucose, $25 \mathrm{mmol} / \mathrm{l} \mathrm{D}$-glucose plus NAC, $25 \mathrm{mmol} / \mathrm{l} \mathrm{D}$-glucose plus Trolox and $5 \mathrm{mmol} / \mathrm{l}$ D-glucose plus BSO, $n=3$ for each condition) at 6,8 and 10 days. The absence of a sub G1 peak also suggested the absence of apoptosis. Mitosis as measured by mitotic figures and $\% \mathrm{G} 2+\mathrm{M}+\mathrm{S}$ at days 6,8 and 10 showed a tendency to increase in $25 \mathrm{mmol} / \mathrm{l} \mathrm{D}$-glucose, $25 \mathrm{mmol} / \mathrm{l} \mathrm{D}$-glucose plus $200 \mu \mathrm{mol} / \mathrm{l}$ Trolox and $5 \mathrm{mmol} / \mathrm{l} \mathrm{D}$-glucose plus BSO and reduce in $25 \mathrm{mmol} / \mathrm{l}$ D-glucose plus $1 \mathrm{mmol} / \mathrm{l} \mathrm{NAC} \mathrm{(Table} \mathrm{5).}$

\section{Discussion}

This work has shown that glucose causes oxidative stress in VSMC in culture. There has been evidence of oxidant damage in the form of increased malondialdehyde and conjugated dienes in human endothelial cells cultured in $20 \mathrm{mmol} / \mathrm{l}$ D-glucose for 10 days [33], but the existence of glucose-induced
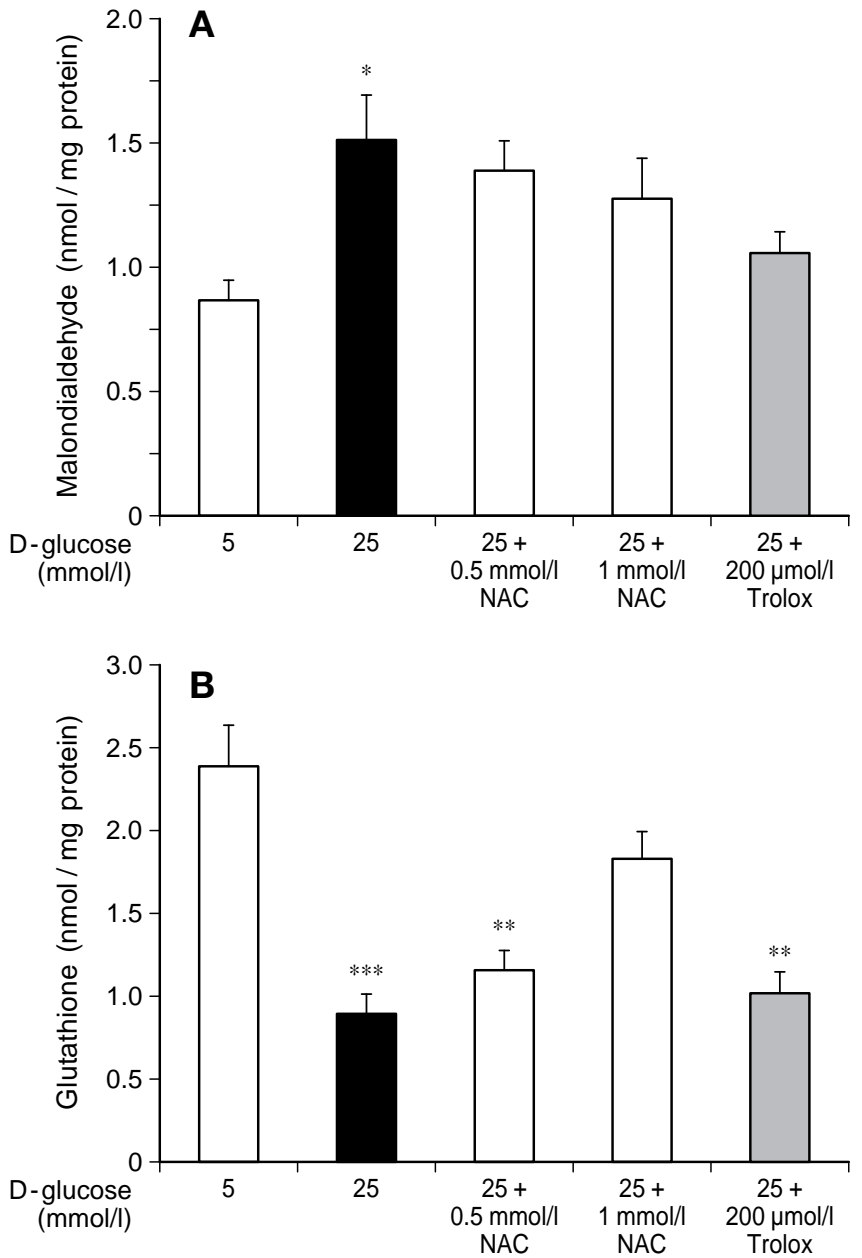

Fig. 4. A Intracellular malondialdehyde in VSMC cultured in $5 \mathrm{mmol} / \mathrm{l} \mathrm{D}$-glucose, $25 \mathrm{mmol} / \mathrm{l} \mathrm{D}$-glucose, $25 \mathrm{mmol} / \mathrm{l} \mathrm{D}$-glucose plus $0.5 \mathrm{mmol} / 1,1.0 \mathrm{mmol} / 1 \mathrm{~N}$-acetyl cysteine (NAC) and $25 \mathrm{mmol} / \mathrm{l} \mathrm{D}$-glucose plus $200 \mu \mathrm{mol} / \mathrm{l}$ Trolox for 10 days. $* p<0.05$ cf $5 \mathrm{mmol} / 1 \mathrm{D}$-glucose. $n=5$ (in duplicate). B Intracellular glutathione in VSMC cultured in $5 \mathrm{mmol} / \mathrm{l} \mathrm{D}$-glucose, $25 \mathrm{mmol} / 1 \mathrm{D}$-glucose, $25 \mathrm{mmol} / \mathrm{l} \mathrm{D}$-glucose plus $0.5 \mathrm{mmol} / \mathrm{l}$, $1.0 \mathrm{mmol} / \mathrm{l} \mathrm{N}$-acetylcysteine (NAC) and $25 \mathrm{mmol} / \mathrm{l} \mathrm{D}$-glucose plus $200 \mu \mathrm{mol} / 1$ Trolox for 10 days. $* * p<0.01$, *** $p<0.001 \mathrm{cf}$ $5 \mathrm{mmol} / \mathrm{l}$ D-glucose. $n=5$ (in duplicate)

oxidant damage in VSMC has not been reported previously.

Various sources of free radicals can contribute to oxidative stress in diabetes, including monosaccharide autoxidation, non-enzymatic glycation of proteins, increased polyol pathway activity and reduced antioxidant reserve. Although malondialdehyde is believed to be a sensitive indicator of free radical activity, oxidative stress does occur in the absence of lipid peroxidation. The upregulation of mRNA expression of antioxidant enzymes is another indicator of intracellular oxidant stress. The increase in MnSOD mRNA expression, in particular, is in keeping with its well recognised induction in response to oxidative stress [34] and increased MnSOD mRNA expression has been noted in endothelial cells cul- 


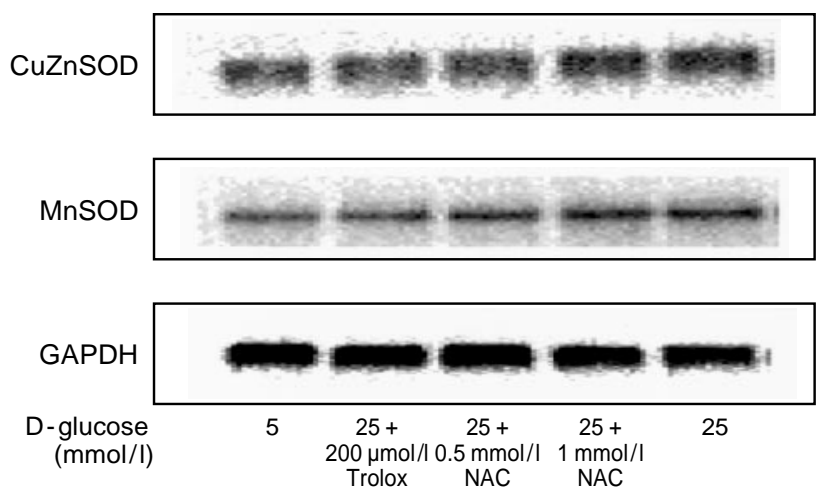

Fig.5. mRNA expression of CuZnSOD and MnSOD in VSMC cultured for 10 days in $5 \mathrm{mmol} / \mathrm{l} \mathrm{D}$-glucose, $25 \mathrm{mmol} / \mathrm{l}$ D-glucose and $25 \mathrm{mmol} / 1 \mathrm{D}$-glucose plus $0.5 \mathrm{mmol} / 1,1 \mathrm{mmol} / \mathrm{l}$ $\mathrm{N}$-acetyl cysteine (NAC)/200 $\mu \mathrm{mol} / 1$ Trolox. GAPDH was used for background correction

tured in high glucose concentrations [35]. Increases in $\mathrm{CuZnSOD}$ mRNA concentrations have also been reported in endothelial cells under similar conditions [35] and in diabetic rat kidneys [36]. These results show, for the first time, the ability of the VSMC to respond to glucose-induced oxidative stress by increasing the mRNA levels of the SOD enzymes (both $\mathrm{Cu}$ ZnSOD and MnSOD). The increase in CuZnSOD protein concentration is consistent with the increase in mRNA expression and the failure to detect an increase in actual enzyme activity can be explained by the fact that CuZnSOD activity is inhibited by glycation of the enzyme [37]; it can also be inactivated by free radicals. The failure to show an increase in MnSOD enzymatic activity despite the increase in mRNA expression was unexpected. Since MnSOD resides within the mitochondria, glycation would seem to be an unlikely event, however, inactivation by increased superoxide radicals is possible.

Glutathione is a key aqueous phase antioxidant in cells and it appears to be important in the VSMC. Its depletion has been reported in plasma, erythrocytes, leucocytes and platelets from patients with diabetes mellitus. Decreases have also been reported in endothelial cells from diabetic rabbits [38] but not in human endothelial cells cultured in $20 \mathrm{mmol} / \mathrm{l} \mathrm{D-glu-}$ cose for 14 days [39]. There have been no previous reports on glutathione concentrations in VSMC. A pos-
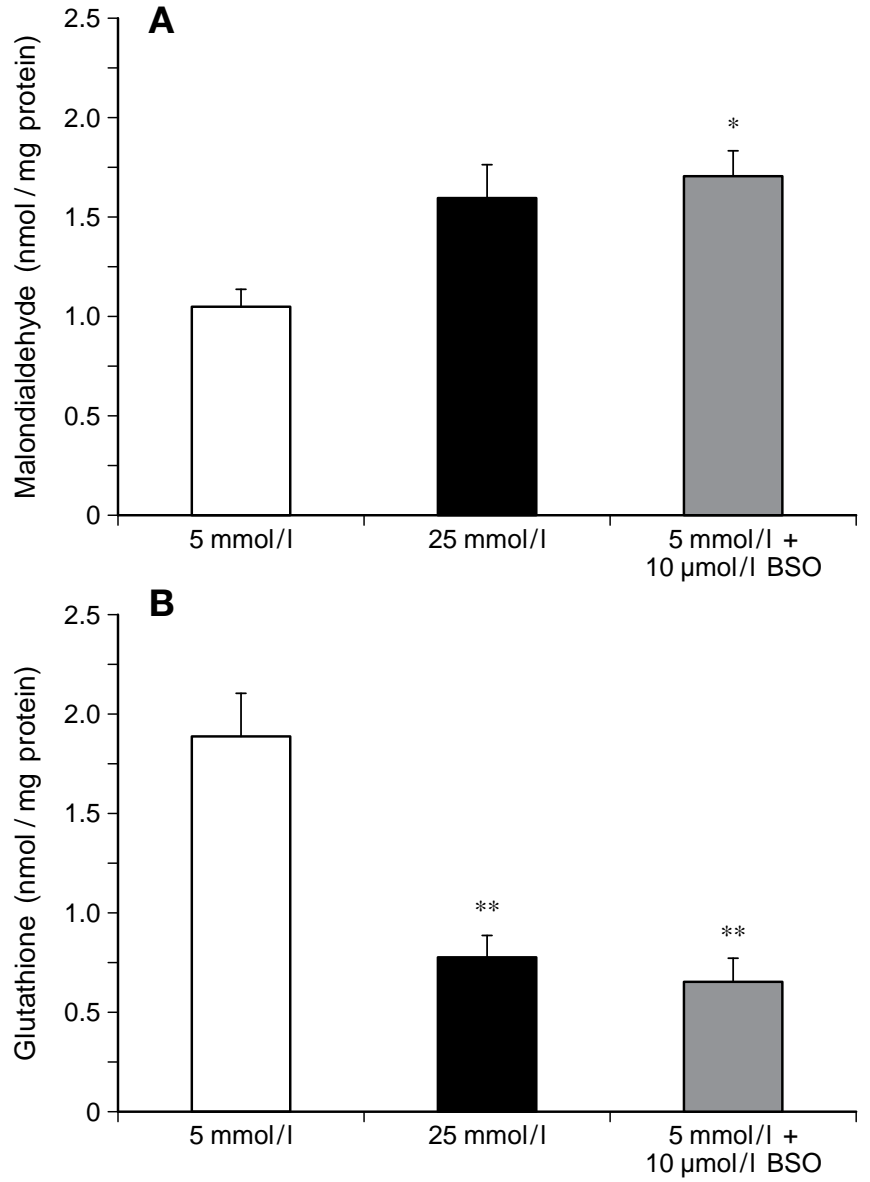

Fig. 6. A Intracellular malondialdehyde in VSMC cultured in $5 \mathrm{mmol} / \mathrm{l} \mathrm{D}$-glucose, $25 \mathrm{mmol} / \mathrm{l} \mathrm{D}$-glucose and $5 \mathrm{mmol} / \mathrm{l} \mathrm{D}$-glucose plus $10 \mu \mathrm{mol} / 1$ buthionine sulphoximine (BSO) for 10 days. ${ }^{*} p<0.05$ cf $5 \mathrm{mmol} / 1 \mathrm{D}$-glucose. $n=5$. B Intracellular glutathione in VSMC cultured in $5 \mathrm{mmol} / \mathrm{l}$ D-glucose, $25 \mathrm{mmol} / \mathrm{l} \mathrm{D}$-glucose and $5 \mathrm{mmol} / \mathrm{l} \mathrm{D}$-glucose plus $10 \mu \mathrm{mol} / \mathrm{l}$ buthionine sulphoximine (BSO) for 10 days. $* * p<0.01 \mathrm{cf}$ $5 \mathrm{mmol} / \mathrm{l} \mathrm{D}$-glucose. $n=5$

sible explanation for the decrease in glutathione could be that the depletion is the primary event which subsequently predisposes the cell to oxidant-induced damage. Several studies have found reductions in both the gene expression and activity of the key rate-limiting enzyme in glutathione synthesis, gamma glutamyl cysteine synthetase ( $\gamma$-GCS) with high glucose concentrations [40, 41]. It has been suggested that the glucose-derived modification of the $\gamma$-GCS

Table 5. Mitotic indices of VSMC at days 6, 8 and 10 cultured in different conditions

\begin{tabular}{|c|c|c|c|c|c|c|}
\hline \multirow[t]{2}{*}{ Condition } & \multicolumn{3}{|c|}{ Mitotic figures \% } & \multicolumn{3}{|c|}{$\% \mathrm{G} 2+\mathrm{M}+\mathrm{S}$} \\
\hline & Day 6 & Day 8 & Day 10 & Day 6 & Day 8 & Day 10 \\
\hline 5 mmol/l D-glucose & $2.34 \pm 0.29$ & $1.47 \pm 0.48$ & $1.93 \pm 0.62$ & $30.3 \pm 6.7$ & $18.8 \pm 2.1$ & $17.2 \pm 2.2$ \\
\hline $25 \mathrm{mmol} / \mathrm{l} \mathrm{D}$-glucose & $2.64 \pm 0.21$ & $1.71 \pm 0.40$ & $1.89 \pm 0.61$ & $29.8 \pm 6.0$ & $22.3 \pm 3.9$ & $21.2 \pm 2.6$ \\
\hline $25 \mathrm{mmol} / \mathrm{l}+200 \mu \mathrm{mol} / \mathrm{l}$ Trolox & $2.82 \pm 0.19$ & $1.76 \pm 0.55$ & $2.12 \pm 0.80$ & $27.7 \pm 6.4$ & $18.2 \pm 1.6$ & $25.3 \pm 4.5$ \\
\hline $25 \mathrm{mmol} / \mathrm{l}+1 \mathrm{mmol} / \mathrm{l} \mathrm{NAC}$ & $1.59 \pm 0.43$ & $1.18 \pm 0.31$ & $1.54 \pm 0.46$ & $28.6 \pm 7.5$ & $15.6 \pm 2.0^{\mathrm{a}}$ & $16.0 \pm 1.1$ \\
\hline $5 \mathrm{mmol} / \mathrm{l}+1 \mu \mathrm{mol} / \mathrm{l} \mathrm{BSO}$ & $2.46 \pm 0.22$ & $1.73 \pm 0.57$ & $1.85 \pm 0.43$ & $30.1 \pm 6.1$ & $23.9 \pm 5.4$ & $22.0 \pm 0.9$ \\
\hline
\end{tabular}

$n=4$ independent experiments for mitotic figures and $\% \mathrm{G} 2+\mathrm{M}+\mathrm{S},{ }^{\mathrm{a}} p<0.05 \mathrm{cf} 5 \mathrm{mmol} / \mathrm{l} \mathrm{D}$-glucose 


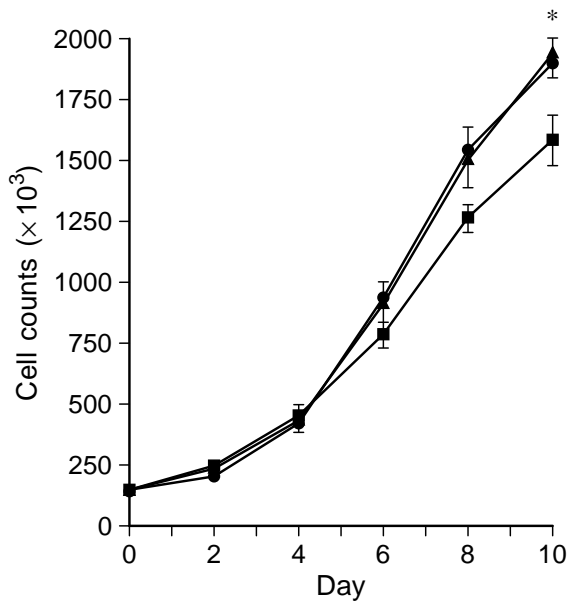

Fig. 7. Growth curves of VSMC cultured in $5 \mathrm{mmol} / \mathrm{l} \mathrm{D}$-glucose, $25 \mathrm{mmol} / \mathrm{l}$ D-glucose and $5 \mathrm{mmol} / \mathrm{l} \mathrm{D}$-glucose plus $10 \mu \mathrm{mol} / 1$ buthionine sulphoximine (BSO) for 10 days. $* p<0.05,25 \mathrm{mmol} / \mathrm{l}$ and $5 \mathrm{mmol} / \mathrm{l}$ plus $10 \mu \mathrm{mol} / \mathrm{l} \mathrm{BSO}$ vs $5 \mathrm{mmol} / \mathrm{l} . n=3 \longrightarrow-5 \mathrm{mmol} / \mathrm{l} \mathrm{D}$-glucose, $-\boldsymbol{A}-25 \mathrm{mmol} / \mathrm{l}$ D-glucose, $\cdots \bullet 5 \mathrm{mmol} / \mathrm{l} \mathrm{D}$-glucose $+10 \mu \mathrm{mol} / \mathrm{l} \mathrm{BSO}$

enzyme, possibly by glycation, predisposed the erythrocyte to oxidative stress [41]. This mechanism could also be the one responsible for decreased glutathione in VSMC which would predispose them to oxidantmediated damage. It is also possible that reactive oxygen species rather than glucose itself are responsible for inactivation of $\gamma$-GCS; therefore, glucose-induced oxidative stress could be the cause, rather than the effect of $\gamma$-GCS inactivation.

The increased replication rate of VSMC in high ambient glucose is consistent with the results of others $[10,42]$. In a study with hepatic stellate cells, malondialdehyde added to the substratum of the cells led to an increase in growth [43]; this provides evidence that products of free radical damage can stimulate cellular growth, at least when added exogenously. The effects of the antioxidants NAC and Trolox and of the $\gamma$-GCS inhibitor BSO [44], made it possible to define the importance of thiol status on growth characteristics of VSMC. The first antioxidant, NAC, is a thiol-containing compound which enters cells readily and serves as a precursor for glutathione by replenishing the intracellular pool of cysteine, so that the availability of this amino acid is no longer a limiting factor in glutathione synthesis [45]; NAC also possesses inherent free-radical scavenging effects itself [46]. The second antioxidant Trolox, a water soluble vitamin $\mathrm{E}$ analogue, was used rather than $\alpha$-tocopherol because, in contast to $\alpha$-tocopherol, it does not inhibit PKC [47]; it exerts major chain-breaking antioxidant effects and is readily transported across the cell membrane. In the $5 \mathrm{mmol} / \mathrm{l}$ glucose, BSO lowered glutathione and raised malondialdehyde to levels found with high glucose; it had the same effect on cell growth as $25 \mathrm{mmol} / \mathrm{l}$ glucose and this suggests that intracellular oxidative stress could be an important activator of VSMC growth. It was not clear from the BSO experiments whether lipid peroxides or thiol status (or both) is the most important in regulating growth. Addition of NAC, which led to repletion of glutathione and reduction in malondialdehyde, restored growth curves to normal even though the upregulation of mRNA for CuZnSOD and MnSOD was unaltered. Glutathione concentrations remained low in the presence of Trolox but treatment with Trolox was associated not only with reduction of malondialdehyde but also with normalisation of mRNA for CuZnSOD and MnSOD; it had no effect on the growth curves of VSMC. It would seem, therefore, that the effect of glucose on growth in VSMC is mediated through alteration of thiol status rather than lipid peroxides, although effects of the second cannot be excluded entirely as small intracellular increases are possibly not detected by measurement of malondialdehyde. By contrast to the effect of extracellular malondialdehyde on growth of stellate cells [43], cellular concentrations did not seem to have a direct effect on growth of VSMC.

Reductions in intracellular glutathione concentrations would be expected to have a profound effect on total thiol status and on cellular redox potential. It is known that redox status alters the activity of the transcription factors NF- $\mathrm{KB}$ and AP-1 as well as the tumour suppressor gene p53 in a complex manner [48]. $\mathrm{NF}-\kappa \mathrm{B}$ influences the activity of c-myc which is involved in control of the cell cycle [49]; c-fos and c-jun (AP-1) have been implicated in signal transduction processes leading to proliferation [50], and the tumour suppressor gene, p53, is involved in the apoptotic process [51]. Therefore activation of one or other of these transcription factors by altered redox status could potentially be involved in growth of VSMC. The evidence from this work suggests that lipid peroxides do not have a major role in growth regulation when VSMC are exposed to high concentrations of glucose.

Our results also show that aortic VSMC cultured in $25 \mathrm{mmol} / \mathrm{l} \mathrm{D}$-glucose do not display increased gene expression of the extracellular matrix proteins, fibronectin and collagens I, III and IV at 10 days. This suggests that either increased mRNA expression of extracellular matrix proteins does not occur in VSMC in hyperglycaemic conditions or that changes become apparent at other time points. There are numerous reports of increased extracellular matrix proteins (both mRNA expression and protein concentrations) at variable time points and glucose concentrations in differing cell types. For example, in human endothelial cells, mRNA expression of both fibronectin and collagen IV were increased (by approximately $150 \%$ ) after 17 days exposure to $30 \mathrm{mmol} / \mathrm{l}$ glucose [52], whereas others have shown similar changes in endothelial cells after only 5 days in $30 \mathrm{mmol} / \mathrm{l}$ glucose [53]. In human mesangial cells cultured in 
$30 \mathrm{mmol} / \mathrm{l} \mathrm{D}$-glucose, increased mRNA expression of fibronectin, laminin and collagen IV were not apparent at 7 days but were increased at 14 days [54]. There is some suggestion that formation of AGEs (advanced glycation end-products) is an important pathogenic mechanism in upregulation of gene expression of extracellular matrix proteins [55], and under these circumstances the 10 day period of culture could be insufficient. Although increased amounts of these proteins have been identified in the aortae of diabetic subjects [17], their actual cell of origin (endothelial or VSMC), was not clearly identified. Indeed, endothelial cells could be the main source for extracellular matrix expansion. The absence of endothelial influences on VSMC in the tissue culture conditions could also explain the lack of response.

In conclusion, this work has shown the existence of glucose-induced oxidative stress in VSMC and this could be an important mechanism in induction of VSMC dysfunction. The results suggest that thiol status, rather than lipid peroxides, is a key factor in modulating VSMC growth in the presence of high glucose concentrations.

Acknowledgements. This work was supported by the British Diabetic Association (BDA), Northern Ireland Chest, Heart and Stroke Association and the Mason Foundation. P.C. Sharpe was funded through a Royal Victoria Hospital Research Fellowship and M. A. Catherwood was supported by the European Social Fund. We are grateful to Dr. D. McManus (Department of Histopathology, Queen's University of Belfast) for his expertise in counting mitotic and apoptotic cells and Dr. K. Williamson (same department) for her assistance with the flow cytometric analysis. We also thank Prof. E. Vuorio (Department of Medical Biochemistry and Molecular Biology, University of Turku, Turku, Finland) for the gift of plasmids.

\section{References}

1. Jarret RJ (1984) The epidemiology of coronary heart disease and related factors in the context of diabetes mellitus and impaired glucose tolerance. In: Jarret RJ (ed) Diabetes and heart disease. Elsevier, Amsterdam, pp 1-23

2. Pylorala K, Laakso M, Uusitupa M (1987) Diabetes and atherosclerosis: an epidemiologic review. Diab Metab Rev 3: $464-524$

3. Sato Y, Hotta N, Sakamoto N, Matsuoka S, Ohishi N, Yagi K (1979) Lipid peroxide level in plasma of diabetic patients. Biochem Med 21: 104-107

4. Karpen CW, Cataland S, O'Dorisio TM, Panganamala RV (1985) Production of 12 HETE and vitamin E status in platelets from type 1 human diabetic subjects. Diabetes 34: 526-531

5. Ward PA, Till GO, Kunkel R, Beauchamp G (1983) Evidence for role of hydroxyl radical in complement and neutrophil-dependent tissue injury. J Clin Invest 72: 789-801

6. Lorenzi M (1992) Glucose toxicity in the vascular complications of diabetes: the cellular perspective. Diabetes Metab Rev 8: 85-103

7. Baumgartner-Parzer SM, Wagner L, Pettermann M, Grillari, J, Gessl I, Waldhausl W (1995) High-glucose-triggered apoptosis in cultured endothelial cells. Diabetes 44: 1323-1327

8. McVeigh GE, Brennan GM, Johnston GD et al. (1992) Impaired endothelium-dependent and independent vasodilation in patients with type 2 diabetes mellitus. Diabetologia 35: 771-776

9. Ross R (1986) The pathogenesis of atherosclerosis - an update. N Engl J Med 314: 488-500

10. Graier WF, Grubenthal I, Dittrich P, Wascher TC, Kostner GM (1995) Intracellular mechanism of high D-glucose-induced modulation of vascular cell proliferation. Eur J Pharmacol 294: 221-229

11. Rao GN, Berk BC (1992) Active oxygen species stimulate vascular smooth muscle cell growth and proto-oncogene expression. Circ Res 70: 593-599

12. Pfeifle B, Ditschuneit H (1981) Effect of insulin on growth of cultured human arterial smooth muscle cells. Diabetologia 20: 155-158

13. Williams B, Schrier RW (1992). Characterization of glucose-induced in situ protein kinase $\mathrm{C}$ activity in cultured vascular smooth muscle cells. Diabetes 41: 1464-1472

14. Taniguchi N, Kaneto H, Asahi M et al. (1996) Involvement of glycation and oxidative stress in diabetic macroangiopathy. Diabetes 45 [Suppl 3]:S81-S83

15. Palumbo EJ, Sweatt JD, Chen SJ, Klann E (1992) Oxidation-induced persistent activation of protein kinase $\mathrm{C}$ in hippocampal homogenates. Biochem Biophys Res Commun 203: 302-309

16. Sjolund M, Hedin U, Sejersen T, Heldin CH, Thyberg J (1988) Arterial smooth muscle cells express platelet-derived growth factor (PDGF) A chain messenger RNA, secrete a PDGF-like mitogen, and bind exogenous PDGF in a phenotype and growth state-dependent manner. J Cell Biol 106: 403-413

17. Rasmussen LM, Heickendorff L (1989) Accumulation of fibronectin in aortas from diabetic patients: a quantitative immunohistochemical and biochemical study. Lab Invest 61: $440-446$

18. Donnini D, Zambito AM, Perrella G, Ambesi-Impiombato FS, Curcio F (1996) Glucose may induce cell death through a free radical-mediated mechanism. Biochem Biophys Res Comm 219: 412-417

19. Bump EA, Yu NY, Taylor YC, Brown JM, Travis EL, Boyd MR (1983) Radiosensitization and Chemosensitization by Dietylmaleate, Radioprotectors and Anticarcinogens. In: Nygaard OF, Simic MG (eds) Academic Press, New York, pp 297-324

20. Thanos D, Maniatis T (1995) NF-kappa B - a lesson in family values. Cell 80: 529-532

21. Bergelson S, Pinkus R, Daniel V (1994) Intracellular glutathione levels regulate Fos Jun induction and activation of glutathione-S-transferase gene expression. Cancer Res 54: $36-40$

22. Young IS, Trimble ER (1991) Measurement of malondialdehyde in plasma by high performance liquid chromatography with fluorimetric detection. Ann Clin Biochem 28: 504-508

23. Griffith OW (1980) Determination of glutathione and glutathione disulfide using glutathione reductase and 2-vinylpyridine. Anal Biochem 106: 207-212

24. Sharpe PC, Liu WH, Yue KKM, McMaster D, Catherwood MA, McGinty AM, Trimble ER (1998) Glucose-induced oxidative stress in vascular contractile cells: comparison of aortic smooth muscle cells and retinal pericytes. Diabetes 47: 801-809

25. L'Abbe MR, Fischer PWF (1986) An automated method for the determination of $\mathrm{Cu}, \mathrm{Zn}$-superoxide dismutase in 
plasma and erythrocytes using an ABA-200 discrete analyser: Clin Biochem 19: 175-178

26. McMaster D, Bell N, Anderson P, Love AHG (1990) Automated measurement of two indicators of human selenium status, and applicability to population studies. Clin Chem 36: $211-216$

27. Chomczynski P, Sacchi N (1987) Single-step method of RNA isolation by acid guanidinium thiocyanate-phenolchloroform extraction. Anal Biochem 162: 156-159

28. Akasaka M, Mizoguch J, Yoshimura S, Watanabe K (1989) Nucleotide sequence of cDNA for rabbit glutathione peroxidase. Nucleic Acids Research 17: 2136

29. Gunzler WA, Steffens GJ, Grossman A et al. (1984) The amino-acid sequence of bovine glutathione peroxidase. Hoppe-Seyler's Z Physiol Chem 365: 195-212

30. Takahashi K, Akasaka M, Yamamoto Y, Kobayashi C, Mizoguchi J, Koyama J (1990) Primary structure of human plasma glutathione peroxidase deduced from cDNA sequences. J Biochem 108: 145-148

31. Metsaranta M, Toman D, de Crombrugghe B, Vuorio E (1991) Specific hybridisation probes for mouse type I, II, III and IX collagen mRNAs. Biochim Biophys Acta 1089: 241-243

32. Glumoff V, Makela JK, Vuorio E (1994) Cloning of cDNA for rat proa1(III) collagen mRNA. Increased expression of type III collagen gene during induction of experimental granulation tissue. Biochim Biophys Acta 1217: 41-48

33. Curcio F, Pegoraro I, Russo PD, Falleti E, Perrella G, Ceriello A (1995) SOD and GSH inhibit the high glucose induced oxidative damage and the PDGF increased secretion in cultured human endothelial cells. Thromb Haemost 74: 969-973

34. Stralin P, Marklund SL (1994) Effects of oxidative stress on expression of extracellular superoxide dismutase, $\mathrm{CuZn}$ superoxide dismutase and $\mathrm{Mn}$-superoxide dismutase in human dermal fibroblasts. Biochem J 298: 347-352

35. Ceriello A, dello Russo P, Amstad P, Cerutti P (1996) High glucose induces antioxidant enzymes in human endothelial cells in culture. Evidence linking hyperglycemia and oxidative stress. Diabetes 45: 471-477

36. Sechi LA, Ceriello A, Griffin CA et al. (1997) Renal antioxidant enzyme mRNA levels are increased in rats with experimental diabetes mellitus. Diabetologia 40: 23-29

37. Arai K, Iizuka S, Tada Y, Oikawa K, Taniguchi N (1987) Increase in the glucosylated form of erythrocyte $\mathrm{CuZn}$ superoxide dismutase in diabetes and close association of the nonenzymatic glucosylation with the enzyme activity: Biochim Biophys Acta 924: 292-296

38. Tagami S, Kondo T, Yoshida K, Hirokawa J, Ohtsuka Y, Kawakami Y (1992) Effect of insulin on impaired antioxidant activities in aortic endothelial cells from diabetic rabbits. Metabolism 41: 1053-1058

39. Kashiwagi A, Asahina T, Ikebuchi M et al. (1994) Abnormal glutathione metabolism and increased cytotoxicity caused by $\mathrm{H}_{2} \mathrm{O}_{2}$ in human umbilical vein endothelial cells cultured in high glucose medium. Diabetologia 37: 264-269

40. Trocino RA, Akazawa S, Ishibashi M et al. (1995) Significance of glutathione depletion and oxidative stress in early embryogenesis in glucose-induced rat embryo culture. Diabetes 44: 992-998

41. Yoshida K, Hirokawa J, Tagami S, Kawakami Y, Urata Y, Kondo T (1995) Weakened cellular scavenging activity against oxidative stress in diabetes mellitus: regulation of glutathione synthesis and efflux. Diabetologia 38: 201-210

42. Yasunari K, Kohno M, Kano H, Yokokawa K, Horio T, Yoshikawa J (1995) Aldose reductase inhibitor prevents hyperproliferation and hypertrophy of cultured rat vascular smooth muscle cells induced by high glucose. Arterioscler Thromb Vasc Biol 15: 2207-2212

43. Lee KS, Buck M, Houglum K, Chojkier M (1995) Activation of hepatic stellate cells by TGF $\alpha$ and collagen type I is mediated by oxidative stress through c-myb expression. J Clin Invest 96: 2461-2468

44. Griffith OW, Meister A (1979) Potent and specific inhibition of glutathione synthesis by buthionine sulfoximine. J Biol Chem 254: 1205-1210

45. Smilkstein MJ, Knapp G, Kulig K, Rumack B (1988) Efficacy of oral $\mathrm{N}$-acetyl cysteine in the treatment of acetaminophen overdose. N Engl J Med 319: 1557-1562

46. Arouma OI, Halliwell B, Hoey BM, Butler J (1989) The antioxidant action of $\mathrm{N}$-acetylcysteine: its reaction with hydrogen peroxide, hydroxyl radical, superoxide, and hypochlorous acid. Free Radic Biol Med 6: 593-597

47. Boscoboinik D, Szewcyzyk A, Hensey C, Azzi A (1991) Inhibition of cell proliferation by alpha-tocopherol: role of protein kinase C. J Biol Chem 266: 6188-6194

48. Sun Y, Oberley LW (1996) Redox regulation of transcriptional activators. Free Radic Biol Med 21: 335-348

49. Kessler DJ, Duayo M, Spicer DB, Sonenshein GE (1992) $\mathrm{NF}-\kappa \mathrm{B}$ like factors mediate interleukin 1 induction of $\mathrm{c}-$ myc gene transcription in fibroblasts. J Exp Med 176: 787-792

50. Angel P, Karin M (1991) The role of jun, fos and the AP-1 complex in cell proliferation and transformation. Biochim Biophys Acta 1072: 129-157

51. Yonishrouach E (1996) The p53 tumour-suppressor gene a mediator of a G1 growth arrest and of apoptosis. Experientia 52: 1001-1007

52. Roth T, Podesta F, Stepp MA, Boeri D, Lorenzi M (1993) Integrin overexpression induced by high glucose and by human diabetes: potential pathway to cell dysfunction in diabetic microangiopathy. Proc Natl Acad Sci USA 90: 9640-9644

53. Cagliero E, Roth T, Roy S, Lorenzi M (1991) Characteristics and mechanisms of high glucose-induced overexpression of basement membrane components in cultured endothelial cells. Diabetes 40: 102-110

54. Pugliese G, Pricci F, Locuratolo N et al. (1996) Increased activity of the insulin-like growth factor system in mesangial cells cultured in high glucose conditions: relation to glucose-enhanced extracellular matrix production. Diabetologia 39: 775-784

55. Skolnik E, Yang Z, Makita Z, Radoff S, Kirstein M, Vlassara H (1991) Human and rat mesangial cell receptors for glucose-modified proteins: potential role in kidney tissue remodelling and diabetic nephropathy. J Exp Med 174: 931-939 